\title{
Meet the 2021 Diversity Fellows
}

\author{
JASMINE SCOTT | AMERICAN POLITICAL SCIENCE ASSOCIATION
}

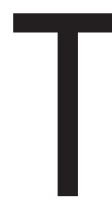

he APSA Diversity Fellowship Program (DFP), formerly the Minority Fellowship Program, was established in 1969 as a fellowship competition to diversify the political science profession. DFP provides support to students from underrepresented backgrounds applying to, or in the early stages of, a PhD program in political science. The goal of the program is to increase the number of scholars from minoritized backgrounds in the discipline and ultimately the professoriate. APSA has once again awarded a new cycle to provide support for students currently in the process of applying to political science PhD program for fall 2021. Please join us in congratulating the 2021-2022 class of fellows. Learn more about APSA's Diversity and Inclusion Programs at https://www. apsanet.org/DIVERSITY/Diversity-and-Inclusion-Programs.

\section{Edward Berdan}

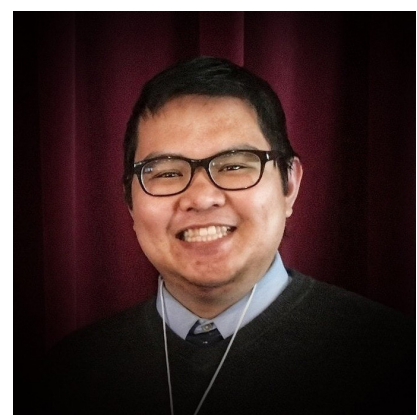

Edward Berdan is a political science master's student focusing on American politics and public policy at California State University, Chico. In his research, Edward explores Asian American and Pacific Islander (AAPI) political participation and voter preference. He won the Betty Nesvold Best Graduate Paper Award for his research exploring the problem of monolithic AAPI analyses at the California State University SSRIC's Social Science Student Symposium in May 2019, and he was a USC POIR Predoctoral Fellow in summer 2019. He has served as a TA for American Government and both undergraduate and graduate research methods courses. As a Filipino American, Edward is passionate about laying the groundwork for future scholars of color. He plans to seek a PhD in political science to contribute to research on AAPI communities and to empower and mentor students of color.

\section{Daisha Campbell}

Daisha Campbell is a senior majoring in political science at California State University, Dominguez Hills. Campbell is a
McNair scholar with research interests including comparative politics and international relations within the subfields of international political economy, trade, Latin America, and US relations. Campbell wants to encourage minority students to study political science as well as increase the scope of diverse perspectives in the field of international political economy.

\section{Latesia Coleman}

Latesia Coleman is an associate researcher with the University of South Florida's EcoFemLab, STEM curriculum strategist focused on lessons integrating social justice, and a mathematics teacher. She is receiving a master's in STEM education in the spring of 2021. Coleman serves as a research associate on several projects that partner

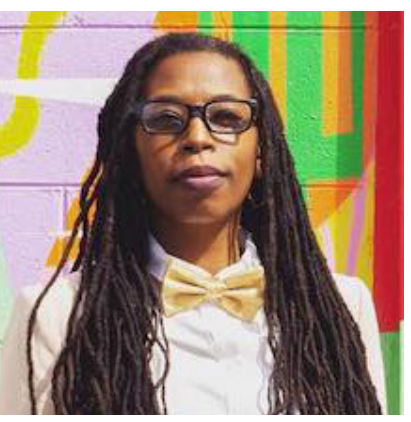
to engage 50 high school students as junior researchers collecting local real time data and using GIS to help us understand the environmental, structural, financial, and medical patterns in specified local communities responding to COVID-19, air quality, and harmful algae blooms. Coleman hopes to concentrate in mixed methods and social justice policies in a PhD program.

\section{Luis Delgadillo}

Luis Pablo Delgadillo is a senior double-majoring in government and Spanish with a minor in Latin American studies at Cornell University. He was a summer fellow for the Virtual Ralph Bunche Summer Institute in 2020. Delgadillo is interested in the role of race and ethnic politics and immigration in the development of social movements.

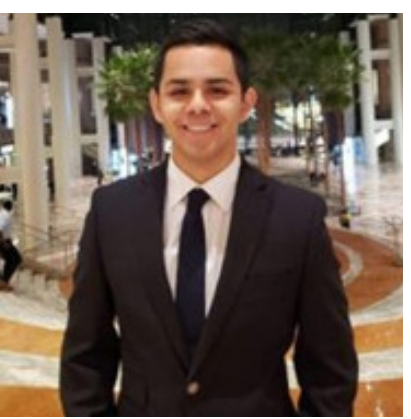
His current research project explores the conditions under which immigrants undergo a process of deculturalization. Delgadillo presented this research at the 2020 Emerging Scholars Conference at the University of Michigan. His future research focuses on the role of indigenous groups in democratization and their interaction with social movements and political parties. He is ea- 
ger to continue analyzing the development of social movements in Latin America from a comparative perspective. Delgadillo plans to continue his research in a PhD program and contribute to the understanding of identity and collective action.

\section{Triston Ferguson}

Triston Ferguson is a senior at the University of North Texas majoring in political science and minoring in communications with a certification in legal studies through a dual degree BA/master's program. He currently serves as vice president \& academic chair of the Delta Epsilon Psi Fraternity Inc., UNT academic coach, and mem-

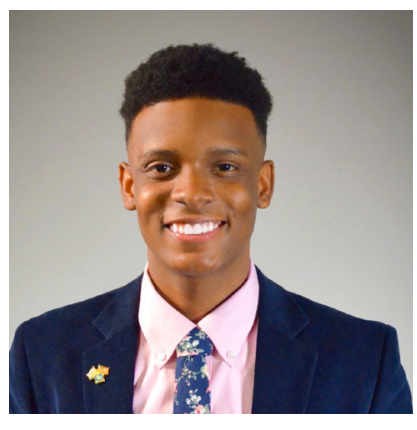
ber of the UNT debate team. Also, he recently served as the vice president of the Alpha Delta Pre-Law Fraternity. During the summer of 2018, he worked as an intern within the US House of Representatives in Washington, DC. Ferguson is particularly interested in political economy and its relation to underrepresented individuals. Ferguson wishes to develop policy methods and recommendations towards mitigating the inherent harmful effects of institutional barriers.

\section{Aura Gonzalez}

Aura Gonzalez received her bachelor's in international studies and political science from the University of California, San Diego in 2020 and her associate's degree from San Diego Mesa College in 2017. She is interested in studying how inheritances, institutions, social cleavages, and political parties shape marginalized

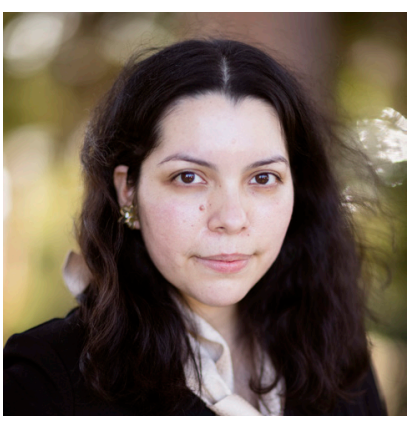
groups' social and developmental outcomes in developing countries. Gonzalez's current project analyzes electoral, census, and policy data from the government of India to explore how local party competition shapes West Bengal's provision of state-funded latrines. She is currently a research assistant on several randomized control trials, observational studies, and mixed-methods papers that address questions in comparative politics spanning ethnic conflict, internal migration, and political economy in South Asia. Gonzalez hopes to earn a doctoral degree in comparative politics and methods to further her skills as a researcher, help foster diversity in the academic community, and develop a network of colleagues with which to collaborate.

\section{Lindsey González}

Lindsey Paola González is a senior at Texas A\&M University. As a joint-degree candidate, she will earn both a bachelor's in political science and a master's of public administration in 2021. She currently works as a graduate research assistant studying diversity in higher education. González has additional experience researching the nonprofit sector, immigration policy, and political participation. In her graduate studies, she acts as the research and data manager of a capstone project investigating emerging technologies in local government. Additionally, González actively participated in efforts of diversity and inclusion at the university level. She proudly mentors and uplifts first-generation college students and other underrepresented groups at Texas A\&M.

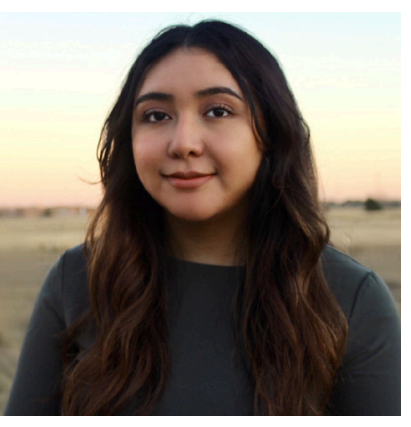
González is interested in the subfields of American politics, racial and ethnic politics, and methodology. She plans to investigate the connection between American political institutions and inequality as a political science PhD student.

\section{Aryssa Harris}

Aryssa Harris is a senior at Beloit College majoring in political science and sociology with a minor in Spanish. As an RBSI Alumni, a Ronald E. McNair Scholar, a two-year president of Black Students United, and a student representative serving on Beloit College's Board of Trustees, she shows that she takes initiative and has a

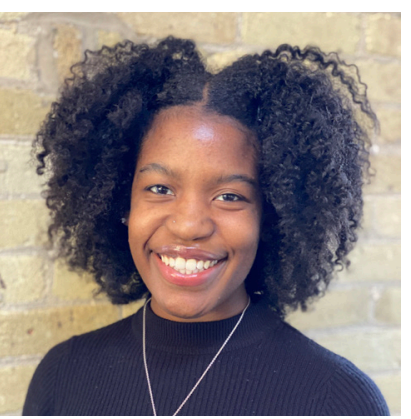
passion for leading. As a Ronald E. McNair Scholar, she has conducted research on the disparate impact of mass incarceration on Black males, in relation to the War on Drugs. Harris' research interests include American politics, public policy, and racial and ethnic politics. Harris would like to use her political science knowledge to represent underrepresented individuals in legal settings.

\section{Sarah Hayes}

Sarah Hayes is currently a master's student studying political science at the University of California, Riverside with a focus in American politics and mass political behavior. She received her undergraduate degree in psychology at the California State University, Fresno, where she was also a McNair scholar. Informed by her work as a

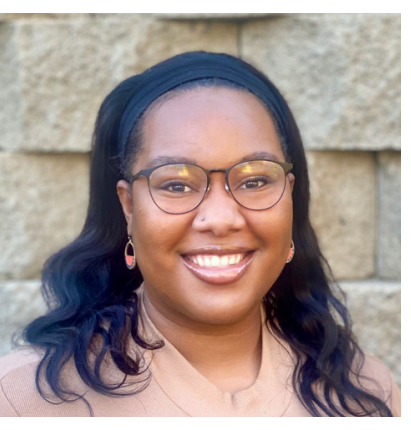
California campaign organizer and public health researcher, Hayes' research interests reside at the intersection of race, health, and politics. Her senior thesis explores how electoral incentives impact legislative responsiveness to COVID-19. During her time at UC Riverside, Hayes has worked as a graduate student research associate for the Center of Social Innovation studying how race impacts civic engagement. In her PhD program, Hayes hopes to study American politics with a focus on developing more accurate measures of formal and informal modes political participation. 


\section{Jasanté Howard}

Jasanté Howard is a senior and AmeriCorps VISTA alumnus majoring in political science at the University of California, Davis, where he is conducting an honors thesis under his adviser, Dr. Rachel Bernhard. This research will be a historical analysis of racial appeals and respectability politics as engaged by Black congresspeople. He was invited

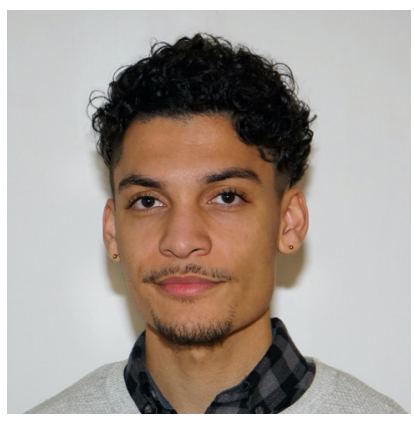
to present this project at the University of Michigan's Emerging Scholars Conference in fall of 2020. Howard's research interests are heavily influenced by his personal experiences as an African American from Virginia, having endured homelessness, poverty, and racism-themes he intends to explore further at the $\mathrm{PhD}$ level. He is currently also coauthoring a project analyzing race, respectability, and political ambition with his advisor, as well as Drs. Matthew Hayes and Mirya Holman.

\section{Karla Magaña}

Karla Magaña is a senior honors student studying political science at Boise State University. Her research interests include race and ethnic politics and identity politics intersecting with political institutions and government accountability. As a McNair Scholar, Magaña is currently conducting independent research regarding local

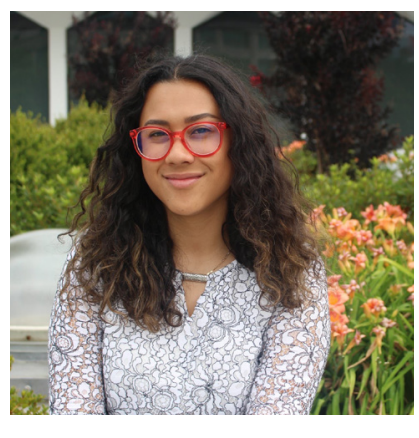
government transparency, Latinx farmworkers, and COVID-19 infection rate. Her interest in Latinx farmworkers stems from her undergraduate research experience as a research assistant at Boise State University as well as a participant in the 2020 MIT Summer Research Program. Magaña has presented her research at the 2020 Emerging Scholars Conference as well as the Boise State Undergraduate Research Conference. Her ambition is to attain her $\mathrm{PhD}$ and become a professor of political science. Magaña hopes to inspire and support other first-generation students of color like herself to pursue careers as scholars.

\section{Eden Melles}

Eden Melles is a senior at Lipscomb University studying political science and history. As an international scholars fellow, she traveled to South Africa to research the lingering impacts apartheid era policies have on educational opportunities and outcomes. Melles also participated in collecting data and constructing a community pro-

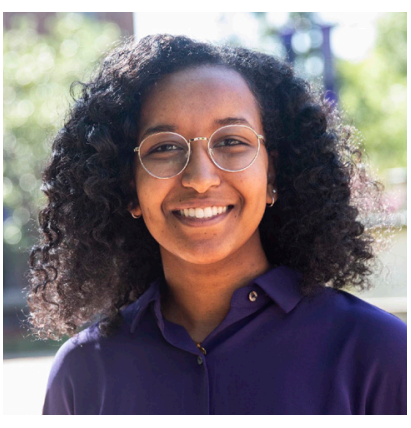

file for a Department of Justice funded grant that helped develop a community-based diversion court in one of the most highly incarcerated zip codes in the country. As a participant in the
Moore Undergraduate Research Apprentice Program at UNC Chapel Hill, she presented a paper that empirically assesses the organizational characteristics that likely lead nonprofits to apply and receive government grants. Her experiences as an Eritrean American woman have served as a basis for her interest in the intersection of race, identity, and politics, and specifically how these factors contribute to political participation. With aspirations of becoming a professor, Melles plans to complete a PhD in political science and center her work on social movements and the political behavior of underrepresented communities.

\section{Chinemelu Okafor}

Chinemelu Okafor is a predoctoral research specialist at Princeton University, where she currently provides advanced statistical analysis to support the work of her faculty mentor. Okafor is also a 2020 Princeton LISD Global Diplomatic and Security Challenges Fellow. Previously, Okafor was an Empirical Studies of Conflict Re-

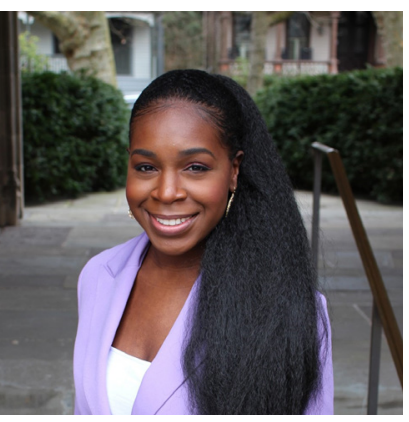
search Specialist in the School of Public and International Affairs at Princeton University. Before coming to Princeton, Chinemelu worked as a research assistant at the International Finance Corporation within the Thought Leadership Unit. Her previous professional experiences include positions at the World Bank, the United Nations, and the Royal African Society. Okafor is also the founder and president of the Research in Color Foundation. As a prospective PhD student, she plans to examine topics such as ensuring the accountability of public officials, exploring the ways social cues and norms shape the behavior of political elites, and how collective reasoning can help shape good governance. Chinemelu holds a master's degree from George Washington University in applied economics and a double bachelor's degree in economics and international studies from the University of Michigan.

\section{Nelson Quezada Herrera}

Nelson Quezada Herrera is an immigrant, first-generation senior at Stetson University with a double major in political science and English. He is a Bonner Scholar and serves as the community outreach intern for CEP, a higher education in prison program. He was also a summer fellow for the Virtual Ralph Bunche Summer Institute

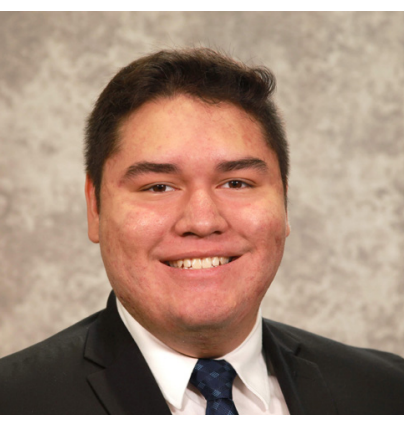
in 2020. His primary research interest is in political behavior, political psychology, and public opinion, especially as it relates to how one can influence people's attitudes towards politics and policies. Quezada Herrera is also interested in racial and ethnic politics, immigration policy, and justice reform. At Stetson, he conducted original research by examining how issue framing and identity priming influenced support for the Green New Deal. He used the findings of his research as the foundation for 
his senior thesis which he then presented at the APSA Annual Meeting in 2020.

\section{Elena Ramirez}

Elena Ruiz Ramirez graduated from California State University, Los Angeles in 2018 with a master's in political science. She received honors and special recognition in graduate studies for outstanding academic performance. Additionally, Ramirez was selected as a Galbraith Fellow by CSULA's Pat Brown Institute for her enthusiasm in

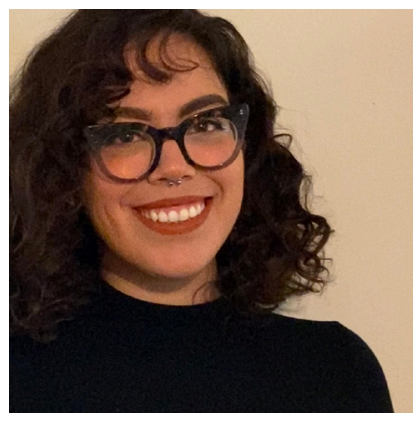
studying environmental politics. Coming from a lineage of Latino migrant farmworkers, Ramirez's research interests center on social and environmental equity for minority communities. For her undergraduate thesis, Ramirez conducted original research about the disproportionate placement of toxic waste sites in communities of a low socioeconomic status. Her thesis was published in Cal Poly Pomona's political science undergraduate journal and was awarded with a departmental scholarship for best paper in environmental studies. Her aspirations of becoming a researcher and an educator are anchored in contributing to the salience of environmental justice within our domestic political economy, in addition to increasing Latinx representation in the field of political science.

\section{Ezekiel Vergara}

Ezekiel Vergara is rising senior majoring in government and philosophy at Dartmouth College. Vergara specializes in political theory, Cuban politics, and the ethics of warfare. Currently, Vergara is writing his honors thesis which examines the ethics of political revolutions. Vergara has also conducted research as a Mellon

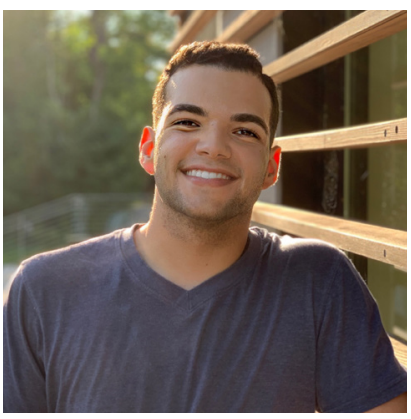
Mays Undergraduate Fellowship Associate Fellow, a James O. Freedman Presidential Scholar, and a Moore Undergradvate Apprenticeship Program Scholar. In 2019, Vergara was awarded the Phillips Family Award in Ethics for his writing on the ethics of punishment. He has also presented his work at Princeton University, Yale University, and the APSA Annual Meeting. Vergara has public policy experience-having worked for local commissioners in Miami and former-Congressman Carlos Curbelo-and has been published in Inquiries Journal. Vergara intends to earn his doctorate in government.

\section{Gabriel Vergara}

Gabriel Vergara is a senior majoring in government with a concentration in political theory at Cornell University. Vergara is a Mellon Mays Undergraduate Fellow and his current research utilizes Antonio Gramsci's political thought in order to inform political mobilization and the maintenance of political alliances. To concretize his theoretical analyses, Vergara uses Fidel Castro as a historical example. This project is part of Vergara's larger goal of putting Latin American thinkers in conversation with mainstream political theorists. At the doctoral level, Vergara intends to examine how Antonio Gramsci's political theory informs the successes and failures of radical and social democracy, following Latin America's

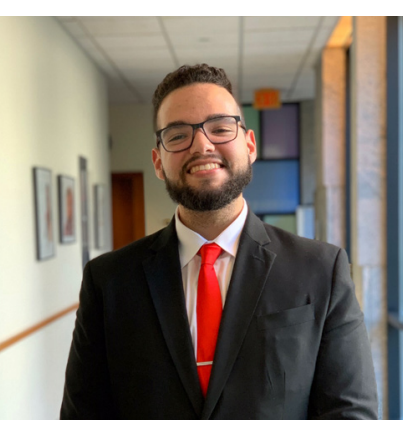
Left Turn. This focus inspires him to pair Gramscian concepts with different Latin American countries, such as Bolivia, Venezuela, and Chile. After earning a PhD in political science, he hopes to join the academy and to serve as a mentor to students of color.

\section{Joseph Yinusa}

Joseph Yinusa is a recent gradvate of the University of Maryland, earning his bachelor's in government and politics with a concentration in international relations. Yinusa's research interests include East Asian politics, with a focus on Chinese and Japanese international relations. Joseph has completed studies related to Chinese con-

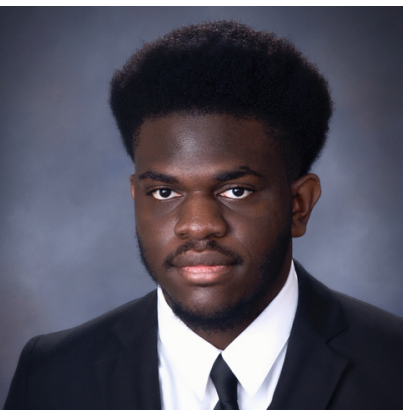
cessional aid, investment, and foreign policy reactions to Uyghur internment and Taiwan's COVID-19 pandemic response. Joseph also presented his findings for his Uyghur internment research at the University of Michigan Department of Political Science's Emerging Scholars Conference for Political Science in November 2020. He is currently a research intern for the Center of Strategic and International Studies' Reconnecting Asia Project. After earning a $\mathrm{PhD}$ in political science, his ultimate career goal is to attain a professorship, wherein he can intellectually guide the next generation of scholars while meaningfully contributing to the field. 